REVISTA X, Curitiba, volume 14, n.5, p. 126-150, 2019

\title{
THE POSTMODERN TURN IN PROSUMING IMAGES: JUXTAPOSITION, DIALOGISM, AND THE SUPPLEMENT IN CONTEMPORARY VISUAL CULTURE
}

A Virada Pós-moderna em Imagens Produzidas e Consumidas Simultaneamente: Justaposição, Dialogismo e Suplemento na Cultura Visual Contemporânea

\author{
Souzana MIZAN (UNIFESP) ${ }^{1}$ \\ Daniel de Mello FERRAZ (USP) ${ }^{2}$
}

\begin{abstract}
This paper aims to problematize the very place of prosuming images (TAPSCOTT; WILLIAMS, 2007), that is, images simultaneously produced and consumed, within the perspectives of the postmodern and the visual turns in contemporary society. Of qualitative/interpretative nature, it discusses and connects such turns to the philosophical concepts of dialogism (BAKHTIN, 1981), cultural translation (MIGNOLO; SCHIWY, 2002; MENEZES DE SOUZA, 2004; HALL, 1997), supplements (DERRIDA, 1978), and visual culture (ROGOFF, 2002; HALL, 1997) by means of interpretations of photographic images from social media (Instagram, Facebook) and free images from websites. The article is divided into 5 sections: after the introduction in which questions of language, representation and visual meaning making are briefly discussed, the second part explores the dialogic nature of language that seeks to juxtapose visual narratives. The third part focuses on the Postmodern and the Visual turns, and suggests that concepts of cultural translation and supplementation are paramount in visual studies. In the fourth section, visual culture - intertwined with cultural translation - is analyzed through the concepts of supplements and ruptures. To conclude, this paper advocates for more critical ways of understanding the socalled crisis of representation in (post) modern society.
\end{abstract}

KEYWORDS: Postmodern turn; visual turn; images; visual culture; language education.

RESUMO: Este artigo tem por objetivo problematizar o lugar de imagens prossumidas (TAPSCOTT; WILLIAMS, 2007), ou seja, imagens produzidas e consumidas simultaneamente, utilizando-se das viradas pós-moderna e visual na sociedade contemporânea. De natureza qualitativa e interpretativista, discute e conecta tais viradas aos conceitos filosóficos de dialogismo (BAHKTIN, 1981), tradução cultural (MIGNOLO; SCHIWY, 2002; MENEZES DE SOUZA, 2004; HALL, 1997), suplemento (DERRIDA, 1978), e cultura visual (ROGOFF, 2002; HALL, 1997) por meio de interpretações de imagens

\footnotetext{
${ }^{1}$ Professora no Curso de Letras na Universidade Federal de São Paulo (UNIFESP). Doutora em Letras pela Universidade de São Paulo (USP) no Programa de Estudos Linguísticos e Literários em Inglês. suzannamizan@hotmail.com

${ }^{2}$ Professor no Curso de Letras na Universidade de São Paulo (USP). Doutor em Letras pela Universidade de São Paulo (USP) no Programa de Estudos Linguísticos e Literários em Inglês. danielferrazusp@gmail.com
} 
fotográficas de mídias sociais (Instagram, Facebook) e imagens livres em websites. O artigo está dividido em 5 seções: após a introdução, em que questões de linguagem, representação e significação visual são brevemente discutidas, a segunda parte explora a natureza dialógica da linguagem, a qual busca justa por narrativas visuais. A terceira parte centra-se nas viradas pósmoderna e visual, e sugere que os conceitos de tradução cultural e suplementação são primordiais para os estudos visuais. Na quarta seção, cultura visual e tradução cultural são analisadas por meio dos conceitos de suplemento e ruptura. Para concluir, a pesquisa defende formas mais críticas de entender a chamada crise de representação na sociedade (pós) moderna.

PALAVRAS-CHAVE: Virada pós-moderna; virada visual; imagens; cultura visual; educação linguística.

\section{INTRODUCTION: IS THERE A CRISIS OF REPRESENTATION?}

In times of extreme violence of all kinds - symbolic, but also physical - towards those who are different, simply for being different and for not belonging to the white heteronormative upper/middle class, the Turkish artist Ugur Gallen (2019) incites us with his very shocking, but also provocative photographic works of art. According to Taggart (2018, p. 01), Gallen's “striking images show the gut-wrenching differences between the two worlds, side-by-side.", and by doing this, delivers "a third margin of the river", to borrow a fruitful metaphor by Guimarães Rosa (1962). Three images from Gallen's Instragram were chosen as examples of his art:

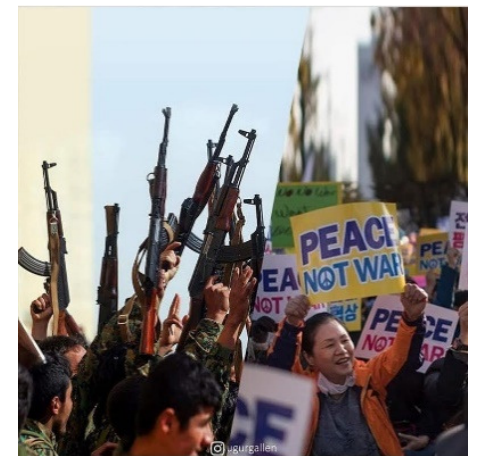

Image $1^{3}-$ Uger Gallen

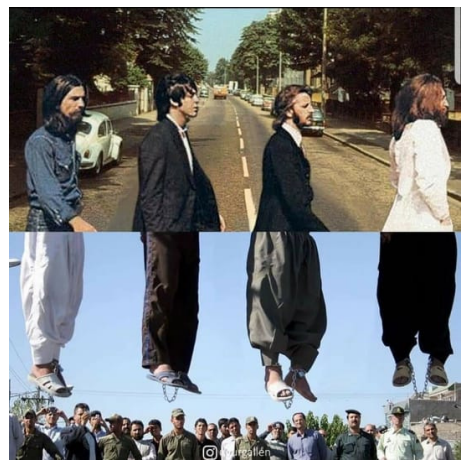

Image 2 - Uger Gallen

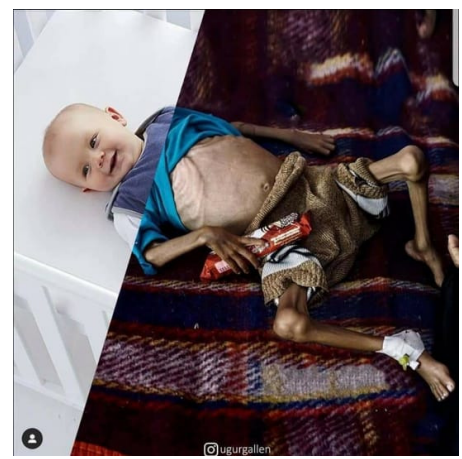

Image 3 - Uger Gallen

Ours is a digital era propelled by new technologies that create the network society which, in its turn, permits everyday users of the digital to become prosumers

\footnotetext{
3 All images 1, 2 and 3 were retrieved from the artist's Instagram profile. Retrieved from: https://www.instagram.com/p/Brsidbnh2Zm/?utm_source=ig_share_sheet\&igshid=04laqv6vox8f. Access on Feb. 20, 2019.
} 
(TAPSCOTT; WILLIAMS, 2007), a concept that merges the words producer and consumer. This new role people assume in the interactive digital networking makes them produce and consume images simultaneously. Prosuming images, therefore, describes processes that take place when images are produced and consumed in digital/virtual spaces, such as our producing and consuming our own Instagram photos. As Kalantzis and Cope (2008) show, in this process the observer becomes the user, for instead of being a passive recipient of mass culture $\mathrm{s} / \mathrm{he}$ becomes an active designer and a developer of new images.

The process of juxtaposition used by Gallen produces virtual "contact zones" (PRATT, 1992, p. 04), since the visual approximation of very distinct realities and unquestionably distant creates a space where cultures meet and interact. The privileged and the underprivileged are brought close to each other in order to devise a fruitful aspect of Gallen's art, the fact that images are powerful tools which instantly dislocate our "eyes" by forcing us to embrace other meaning makings: we are called to envision other possibilities of critically looking at/with the Other.

Rogoff contends that "In today's world meanings circulate visually, in addition to orally and textually. Images convey information, afford pleasure and displeasure, influence style, determine consumption and mediate power relations" (ROGOFF, 2002, p. 25). Still in the words of the author, "who we see and who we do not see; who is privileged within the regime of specularity; which aspects of the historical past actually have circulating visual representations and which do not" (ROGOFF, 2002, p. 02) are some of the questions to be problematized when one thinks of images and their circulation in contemporary times.

In Brazil, the wave in favor of gun liberation, dictatorial governmental decisions, and the elimination of minorities of all kinds are the hallmarks of contemporary public policies. Fake news is said to be the main apparatus used to either convince one side was right (the Right-wing parties) and refute the other side (the Left-wing parties) in 2018 presidential elections. From both sides, Brazilians witnessed a dispute based upon accusations, and lack of dialogue (we actually elected a president who did not show up for the main mass media TV debates) unprecedented in our History. Sadly, this lack of dialogue continued to be the case after the elections since supporters of the Right and the Left have been using social media "bubbles" to construct their realities. In all of these contexts fake news and images have been intrinsically connected to purposefully 
represent the truth, leading to a crisis of representation in which the citizens are not able to either check the sources of those news or make up their mind in relation to them: images and fake news swallowed the naïve elector.

Thus, is there a crisis of representation in relation to images that circulate mostly online - nowadays? According to Hall one should ask: "how does language construct meanings? How does it sustain the dialogue between participants which enables them to build up a culture of shared understandings and so interpret the world in roughly the same ways?" (HALL, 1997, p. 01). In order to answer these questions we need to discuss what we mean by visual language, meaning making, and representation. In visual representations, "meaning is what gives us a sense of our identity, of those who we are and with whom we 'belong' - so it is tied up with questions of how culture is used to mark out and maintain identity within and difference between groups" (HALL, 1997, p. 03).

Meaning, for Bakhtin, is established through dialogue, and is the result of the interaction and interplay with another subject. In the words of the author, "the word in language is half someone else's. It becomes one's own only when the speaker appropriates the word, adapting it to his own semantic expressive intention", meaning that "prior to this, the word does not exist in a neutral or impersonal language...rather it exists in other people's mouths, serving other people's intentions it is from there that one must take the word and make it one's own" (BAKHTIN, 1935, p. 239-240 apud HALL, 1997, p. 235). Thus, meaning, for both Hall and Bakhtin, is not only tied to one's culture(s), but also produced within the dialogic interaction of the subject with the context. This goes for visual meanings.

Hall (ibid.) goes on to argue that language operates through representational systems, which means that "in language, we use signs and symbols - whether they are sounds, written words, electronically produced images, musical notes, even objects - to stand for or represent to other people our concepts, ideas and feelings" (HALL, 1997, p. 01). For Hall (ibid.), "the relation between things, concepts and signs lies at the heart of the production of meaning in language. The process which links these three elements together is what we call representation" (HALL, 1997, p. 19).

Language is then "one of the 'media' through which thoughts, ideas and feelings are represented in a culture" (ibid.). This means that language is produced by the meanings that communities and their individuals share in specific contexts and 
historical times; these meanings together create the representational systems of these communities.

Nation States and nationalism are good examples of how representational systems are put forward by language: Because representation is closely attached to identity, knowledge and context, it is difficult, for example, "to know what 'being English', or indeed French, German, South African or Japanese, means outside of all the ways in which our ideas and images of national identity or national cultures have been represented" (HALL, 1997 p. 05). Returning to Gallen's images, the gaze and thus the relationships are led to the differentiation between two opposing representational systems: those who are wealthy and belong to higher culture, and those who are miserable and belong to the so-called "lower primitive culture".

Perhaps this is why these images are so uncontestedly powerful. In the words of Mirzoeff (1998, p. 03), "this newly visual existence can be confusing. For observing the new visuality of culture is not the same as understanding it" (MIRZOEFF, 1998, p. 03). For him,

[i]ndeed, the gap between the wealth of visual experience in contemporary culture and the ability to analyze that observation marks both the opportunity and the need for visual culture as a field of study. Visual culture is concerned with visual events in which information, meaning or pleasure is sought by the consumer in an interface with visual technology (MIRZOEFF, 1998, p. 03).

Hence Gallen summons us up to do something in relation to this humanity we belong to. Though Gallen's images account for a critique of a global economic capitalist world which splits wealthiness on one side and disenfranchisement by millions of others on the other, it is perhaps the local character of his critique that needs to be problematized: what have we done - in our local communities - in face of disenfranchisement and social differences? Foucault's claims (1994) for the local character of criticism might shed some light in our quest for answers:

So, the main point to be gleaned from these events of the last fifteen years, their predominant feature, is the local character of criticism. That should not, I believe, be taken to mean that its qualities are those of an obtuse, naive or primitive empiricism; nor is it soggy eclecticism, an opportunism that laps up any and every kind of theoretical approach; nor does it mean a self-imposed ascetism which taken by itself would reduce to the worst kind of theoretical impoverishment. I believe that what this essentially local character of criticism indicates in reality is an autonomous, non-centralised kind of theoretical production, one that is to say whose validity is not dependent on the approval of the established regimes of thought (FOUCAULT, 1994, p. 40). 
Therefore, in this article we defend that there is an overabundance of visual representation in which the new technologies and social media span to those who have access to those goods. The local character of criticism, Foucault defended, can be produced by the bricoleurs who deploy visual signs easily accessible to recycle ideas, introduce ruptures to dominant conceptual systems and make silenced voices emerge. This decentralized production of knowledge can be considered as a crisis only by those that opt for dominant, historically "true" and centralized constructions of the "real". Complementing the debate, Tagg (2016) affirms that

\begin{abstract}
the concept of spatial repertoires helps to explain how individuals select resources from their repertoires in any one situation, and suggests that individual repertoires cannot be understood in isolation; as Rymes (2014) argues, repertoires constantly shift and develop to accommodate to interlocutors. As such, repertoires constitute 'constraints and potentialities' (BUSCH, 2014a, p.14) which are realised in interaction; in Busch's words, they are 'formed and deployed in intersubjective processes located on the border between the self and the other' (TAGG, 2016, p. 4).
\end{abstract}

As bricoleurs, the prosumers develop agency by participating actively in the meaning-making processes. Through the recycling of images users of digital media produce, many times collaboratively, new meanings that emerge, and are shared instantly on the internet. In a way new technologies have multiplied, diversified and pluralized the subjectivities that seek to acquire their own voice and perspective on the realities they live in. Without a doubt, this is also the kind of diversity of voices that should emerge in our educational system, in our classrooms and in the corridors of our schools.

Thus, this article theorizes on the diversity that the postmodern visual turn has produced by discussing, in the introduction, questions of language, representation and visual meaning making and exploring the dialogic nature of language that seeks to juxtapose visual narratives in the second part. After that, the third part focuses on the Postmodern and the Visual turns, and suggests that concepts of cultural translation and supplementation are paramount in visual studies. In the fourth section, visual culture intertwined with cultural translation - is analyzed through the concepts of supplements and ruptures. To conclude, this paper advocates for more critical ways of understanding the so-called crisis of representation in (post) modern society and, in order to connect this discussion with language education, it leaves the reader some problematizing/ provocative questions. 


\section{THE DIALOGIC NATURE OF IMAGES IN CONTEMPORANEITY: CONSTRUCTING CONCEPTUAL WORLDS THROUGH VISUAL JUXTAPOSITION}

Ugur Gallen's images in the previous section highlight the bricoleur tendency in producing images in the social media in contemporaneity. Digital technologies supply affordances that allow us to define the internet era as the moment of the remix (ROJO; MOURA, 2012) of an infinite number of images available in the new media. The Turkish artist, situated in a country that is a "contact zone" (PRATT, 1992, p. 04) of the West and the East, has acquired this "double vision" (ALCOFF, 2010, p. 85), simultaneously being conscious of the different takes on the social.

Gallen's juxtaposing of visual narratives exposes the complexity of human experience: The peaceful and the war driven, the fully fed and the starving. The visual narrative created by the artist reveals the heteroglossic nature of visual language in postmodern times that produces the visual "languaging". As Wei and García (2014) elucidate:

Becker (1995) explains: All languaging is what in Java is called jarwadhosok, taking old language (jarwa) and pushing (dhosok) it into new contexts' (185). For Becker, language can never be accomplished; and thus languaging is a better term to capture an ongoing process that is always being created as we interact with the world lingually (WEI; GARCÍA, 2014, p. 08).

The dialogic relationship that is produced uncovers fresh aspects of the concept represented and reveals the agency of the producer of the visual message in an ongoing process of interactive meaning-making. The visual resources are selected and deployed in order to make visible aspects of reality and, hence, induce alterations in our perception of the "real".

A more critical take on the realities depicted and juxtaposed by Gallen would question if the nations portrayed as civilized "are unproblematically democratic and free” (STEINBERG, 2010 apud KINCHELOE et al., 2017, p. 163). There is some kind of distance and, at the same time, closeness that the approximation and interaction of the different sociocultural visual languages, which Gallen portrays juxtaposed, cause. This interaction constructs a dialogism.

\footnotetext{
${ }^{4}$ Pratt (1992) coined the term "contact zones" to refer to social spaces where cultures meet, usually in unequal relations of power in situations such as colonialism or slavery (PRATT, 1992, p. 04).
} 


\begin{abstract}
Dialogism is the characteristic epistemological mode of a world dominated by heteroglossia. Everything means, is understood, as a part of a greater whole-there is a constant interaction between meanings, all of which have the potential of conditioning others. Which will affect the other, how it will do so and in what degree is what is actually settled at the moment of utterance. This dialogic imperative, mandated by the pre-existence of the language world relative to any of its current inhabitants, ensures that there can be no actual monologue. One may, like a primitive tribe that knows only its own limits, be deluded into thinking there is one language, or one may, as grammarians, certain political figures and normative framers of "literary languages" do, seek in a sophisticated way to achieve a unitary language. In both cases the unitariness is relative to the overpowering force of heteroglossia, and thus dialogism (BAKHTIN, 1981, p. 426).
\end{abstract}

The concept of heteroglossia and the pre-existence of the language world relative to any of its current inhabitants lead us to question what the difference is between the scientific and the ideological? Is it possible to teach or to use language to make neutral representations of the world? This is a question being raised by the present Brazilian government, since students are encouraged to denounce teachers who make use of teaching for political, ideological and partisan purposes (Escola sem Partido, 2017). University professors and school teachers are being accused of indoctrinating students and contaminating teaching with leftist ideologies. Escola sem Partido (School without Party Program) is a Bill of Law that seeks to be implemented as part of the guidelines for a National Education Plan (PNE) free of ideology. The position of the government is incongruous with Bakhtin's perceptions on language. The author felt that there is no such thing as a neutral word, free of the intentions and points of view of its authors. In this sense, Tagg contends that

a large body of work has explored the complex ways in which individual linguistic repertoires are drawn on to index identity and signal alignment across contexts...Such studies highlight how people use linguistic resources in dynamic, contextualised, purposeful processes of meaning-making in which 'signs' (PIERCE, 1953) - resources deployed in interaction to convey meaning - are co-constructed and temporarily shared but open to negotiation and change (TAGG, 2016, p. 04).

This means that

in (re-)using signs, speakers engage with these resonances, confirming, challenging or extending the meaning of signs, and anticipating future responses (BAILEY, 2012, p. 499). In this sense, all languaging is dialogic: signs gain meaning through accumulation of past usages and change with subsequent use (TAGG, 2016, p. 05). 
Competing voices emerge in a dialogical conception of language while fixed truths that are considered non-ideological silence the voices of such groups as black people, women, LGBTQIA+ groups whose identities make other realities and histories visible. Doing critical literacy in the educational context means expanding the ways we construct meanings by listening to voices other than the dominant ones. Katherine Schulz sees teaching as listening: "Locating listening at the center of teaching works against the notion that teachers talk and students listen, suggesting instead that teachers listen to teach and students talk to learn" (apud SOUSA SANTOS, 2018, p. 176). Still this opening up to other narratives as a means of educating for difference has been translated into indoctrination. According to such translation, in spite of narratives and history being constructed dialogically, their representation in the classroom should be monological, so to speak, encouraging the movement towards homogeneity, standardization, and traditionalism as has been put forward by Brazilian bills such as School without Party, National Common Core Curriculum and the High School Reform.

Digital technologies permit a much more interactive, collaborative and pluralist virtual reality. The visual texts discussed below, for instance, juxtapose realities and bodies and make them interact while emphasizing that things don't exist in themselves, but only in their relations. Prosumers of visual texts make use of the internet and the social media in general, in order to produce voices on top of voices on top of voices, reshaping meanings by revisiting two or more voices or views in one text. The rereadings, additions and ruptures in the memes below testify on this proliferation of voices that seek to make themselves audible.

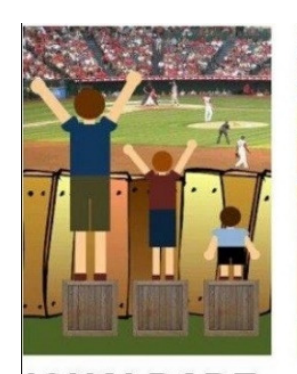

IGUALDADE,

Image $4^{5}$

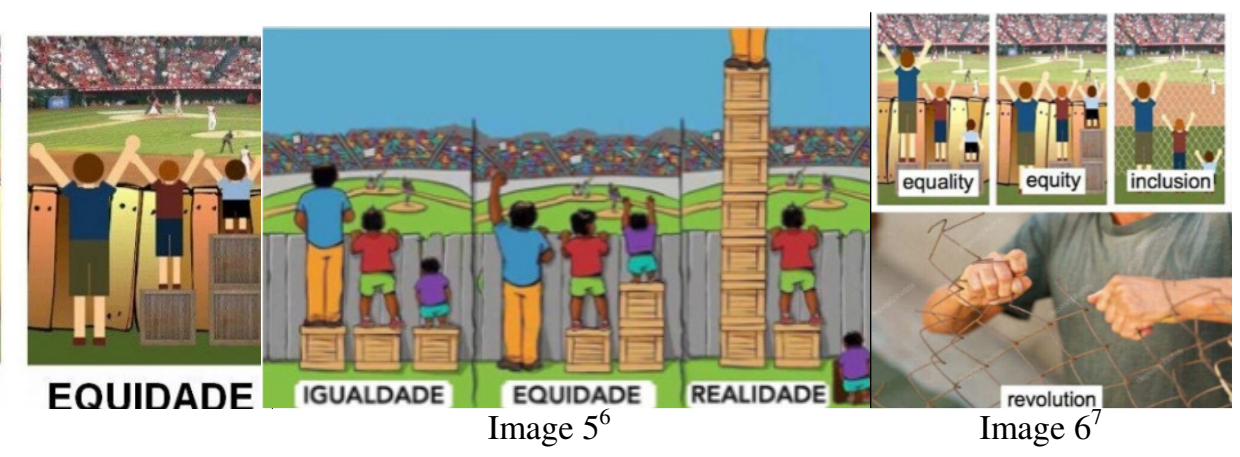

Image $5^{6}$

\footnotetext{
5 Igualdade Equidade. Retrieved from: https://marta-omeucanto.blogs.sapo.pt/igualdade-e-equidade628108. Access on Sept 1, 2019.

${ }^{6}$ Igualdade Equidade Realidade. Retrieved from: https://br.pinterest.com/pin/325455510564931892/ ?lp=true. Access on Sept 1, 2019.

7 Equality Equity Inclusion Revolution. Retrieved from: https://me.me/i/equality-equity-inclusion revolution-ftp-e1098c8d2fae4d4ca90094769707632d. Access on Sept 1, 2019.
} 
The ecology of perspectives on the issue of "equality" that participate in the memes breaks the neutrality and apparent objectivity of the meanings we attribute to the concept. The supplements expand notions and understandings by pluralizing meanings while developing practices for political intervention based onthe dialogic nature of images in contemporaneity. Besides constructing conceptual worlds through visual juxtaposition, visual texts help us dislocate/relocate/critique our own understandings of the world.

\section{THE POSTMODERN TURN AND THE VISUAL TURN: SUPPLEMENTS AS INFINITE EXPANSIONS OF VISUAL AND CONCEPTUAL LANGUAGE}

In the words of Seidman, "The assertion that the west is shifting to a postmodern terrain need not presuppose the end of modernity. The terms 'modern' and 'postmodern' refer to broad social and cultural patterns or sensibilities" (SEIDMAN, 1994, p. 02). Corroborating Bauman, Seidman acknowledges that Modernity is characterized by the "dominance of a culture of control. In the sphere of knowledge, a 'legislative' reason intent on designing and imposing order through categorizing, classifying, and regulating nature and humanity prevails". Yet, there is a search for general principles, and the quest for certainty and foundations. Postmodernity, on the other hand, "features a process of dedifferentiation or the collapse of boundaries and a loss of an epistemic and social centre. The social world is fragmented into a multitude of communities, cultural traditions, and knowledges" (SEIDMAN 1994, p. 14).

In relation to the postmodern condition, Lyotard contended: "I define postmodern as incredulity toward metanarratives" (LYOTARD, 1984, p. 27). Unquestionably, Lyotard is considered one of the most prominent scholars of Postmodernity for having theorized The Postmodern Condition as an essential debate over knowledge put forward by contemporary/modern societies. Lyotard declares "the decline of the legitimating power of 'metanarratives' as distinctive of postmodern culture" (apud SEIDMAN, 1994, p. 05). Metanarratives refer to foundational theories (theories of knowledge, morality, or aesthetics) and grand stories of social progress which have been central to the legitimation of modern knowledge, culture, and social institutions in modern nation states.

Such knowledges abandon absolute standards, universal categories, and grand theories; instead they favor local, historically contextualized, and pragmatic types of 
social inquiry. Thus, the value of postmodern knowledges lies in making us aware of and tolerant toward social differences, ambiguity, and conflict. For Shohat and Stam (2002) the clash between the questions of modernism and postmodernism, or modernity and postmodernity as Mignolo (2000) would frame it

\begin{abstract}
are usually 'centered' within the limited and ultimately provincial frame of European contexts. The emerging field of 'visual culture', for us, potentially represents a break with the Eurocentrism of conservative 'good eye' art history" and the presumably radical, high-modernist avant-gardism" (SHOHAT; STAM, 2002, p. 37).
\end{abstract}

In many ways, people in industrialized and post-industrial societies now live in visual cultures to an extent that seems to divide the present from the past. Popular journalism constantly remarks on digital imagery in cinema, the advent of postphotography and developments in medical imaging, not to mention the endless tide of comment devoted to the Internet IBid. This globalization of the visual, taken collectively, demands new means of interpretation. At the same time, this transformation of the postmodern present also "requires a rewriting of historical explanations of modernism and modernity in order to account for 'the visual turn"” (MIRZOEFF, 1998, p. 4). Postmodernity is not, of course, simply a visual experience. In what Arjun Appadurai has called the "complex, overlapping, disjunctive order" of postmodernism, such tidiness is not to be expected (APPADURAI, 1990 apud MIRZOEFF, 1998, p. 04).

What would characterize a postmodern turn in producing, consuming and constructing meaning of visual languages, of the so to speak Visual Turn? The most notable characteristic would be the accelerated production, distribution and storage of images because of new technologies and social media. The availability of a huge number of images on the internet makes people access, by putting key words on google, different kinds of images that broaden their perspective on the topic being researched.

To illustrate our argument we typed "representations of the female" (the key words) on Google ${ }^{8}$ and we got the selection below as first results of our google search. The juxtaposition of all kinds of visual representations on the same google page amplify the visual discourse on the female bodies and subjectivities. We get on our screen a selection of representations of women in the media (the MAC advertisement, older ads,

\footnotetext{
${ }^{8}$ Access on April 23, 2019.
} 
music videos, movies), covers of books that talk about representations of female subjects in different places and times (early modern England, classicist to contemporary Italy, 20th century England), gender representations, medical and historical representations of the female body exhibited in university libraries, two images that talk about representations of African American women in Hip-Hop / Rap culture and a book titled Recovering the black female body and finally two sculptures that represent the female form in Hinduist and Buddhist traditions. By studying the sites the images were taken from, we see a predominance of educational sites that proves that Web 3.0 knows individual browsing habits and identities.

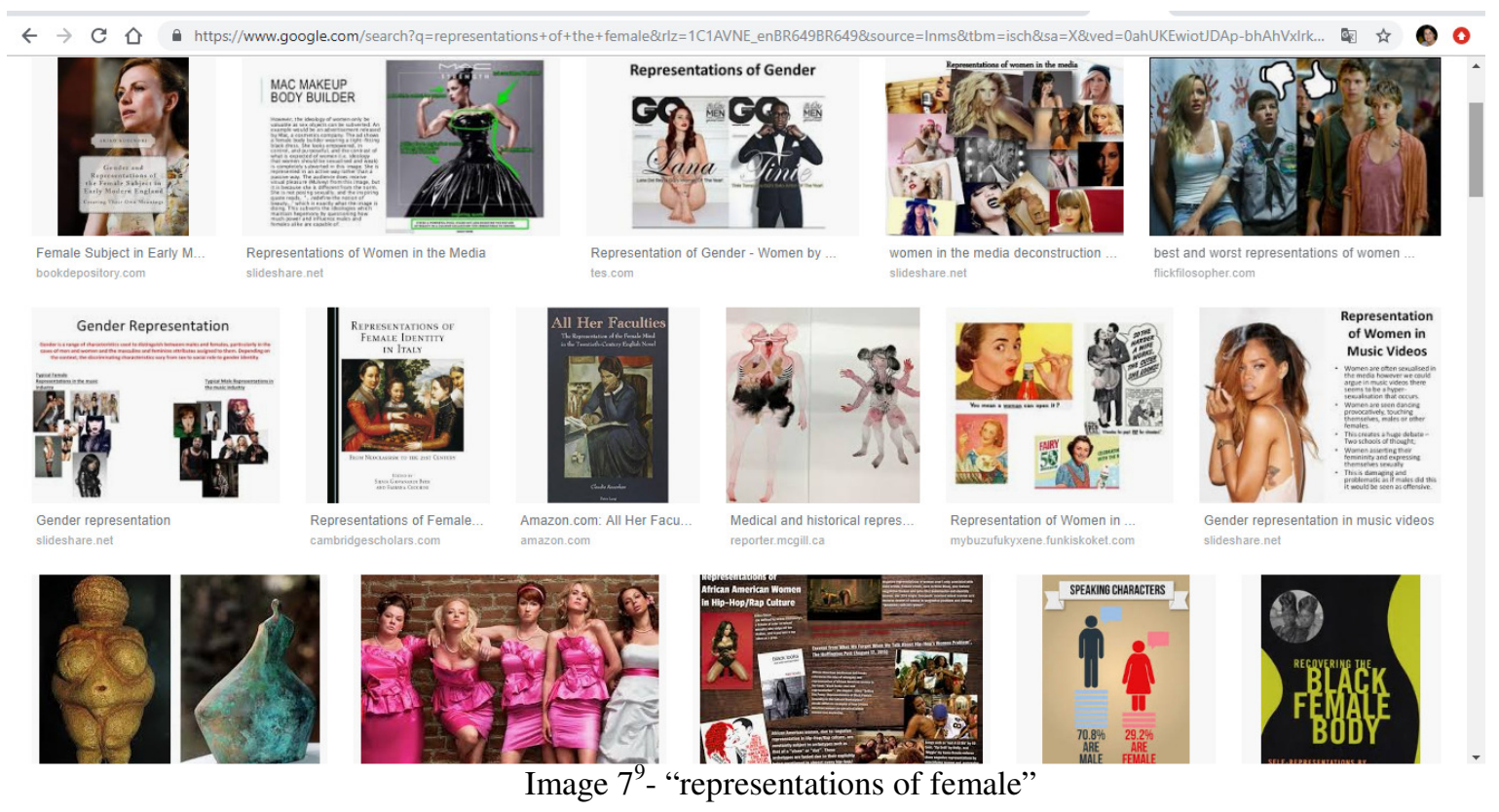

According to Google's website, algorithms are systems of classification that organize billions of webpages to show the end user the most relevant pages according to the identity of the searcher and the meaning Google attributes to the concepts being used $^{10}$. Therefore, Google needs to develop linguistic models in order to decipher the word sequences in their index. This involves applying some of the latest studies on the understanding of language. The assortment of visual representations of the female above is the result of the combination of the two words and the authors' identities. The images

\footnotetext{
${ }^{9}$ Representations of female. Retrieved from:

https://www.google.com/search?q=\%22representations+of+female\%22\&sxsrf=ACYBGNRCmxAZpxU6 4hNVSlwSJ7_ST-9O5Q:1572999153405\&source=lnms\&tbm=isch\&sa=X\&ved=0ahUKEwje95SptTlAhVaGbkGHZBhB7AQ_AUIEigB\&biw=1366\&bih=586 Access on April 23, 2019.

${ }^{10}$ Retrieved from: https://www.google.com/search/howsearchworks/algorithms/ Access on April 23, 2019.
} 
that are shown as first results on google signal the visual deconstruction of historically perpetuated models of the female although the search engine uses linguistic patterns. Rogoff (2002) associates visual and verbal displacements as part of the deconstructive project of early postmodernism:

If feminist deconstructive writing has long held the place of writing as the endless displacement of meaning, then visual culture provides the visual articulation of the continuous displacement of meaning in the field of vision and the visible (ROGOFF, 2002, p. 25).

Although there is a prevalence of the white female body in the representations above and the black and Asian female bodies are still marginalized by Google's algorithms, the assortment of images express the displacement of default representations of the female that has been occurring in conceptual worlds. We can observe that Google, so to say, performs an "archeology" and "genealogy" of the female representation:

If we were to characterize it in two terms, then 'archeology' would be the appropriate methodology of this analysis of local discursivities, and 'genealogy' would be the tactics whereby, on the basis of the descriptions of these local discursivities, the subjected knowledges which were thus released would be brought into play (FOUCAULT, 1994, p. 44).

The genealogy tactics would permit a rupture in dominant visual discourses that research mainly the representation of white female bodies and would "attempt to emancipate historical knowledges from that subjection, to render them, that is, capable of opposition and of struggle against the coercion of a theoretical, unitary, formal and scientific discourse" (FOUCAULT, 1994, p. 44). The absence of Asian female bodies (there are only artistic representations brought forward by the sculptures shown in the image above) and the low occurrence of black bodies point to subjectivities that have been invisible and therefore silenced. Therefore, their subjugated knowledges have been subjected historically to hierarchical orders of power in relation to knowledge since they belong to bodies and conceptual worlds that tend to produce

a particular, local, regional knowledge incapable of unanimity and which owes its force only to the harshness with which it is opposed by everything surrounding it - that it is through the re-appearance of this knowledge, of these local popular knowledges, these disqualified knowledges, that criticism performs its work (FOUCAULT, 1994, p. 41). 
The displacement of dominant knowledges causes the appearance of knowledges that have been other and that belong to subjectivities and bodies historically invisible. These displacements are "the movement of supplementarity" (DERRIDA, 1978, p. 289). This movement demonstrates the impossibility of determining a center and exhausting "totalization because the sign which replaces the center, which supplements it, taking the center's place in its absence - this sign is added, occurs as a surplus, as a supplement" (DERRIDA, 1978, p. 289). The deconstruction of the metaphysics of presence "is first and foremost an affirmation of what is excluded and forgotten-an affirmation, in short, of what is other" (PETERS; BIESTA, 2009, p. 90).

\section{CULTURAL TRANSLATION: SUPPLEMENTS AS EVENTS IN THE FORM OF RUPTURES AND REDOUBLINGS}

Moreover, the postmodern collapse or blurring of the hierarchical distinction between high art and popular art (SEIDMAN, 1994, p. 02) has created resistance from both sides. Indeed, high art is not socially neutral, since it represents the tastes and culture of the upper social classes while being critical to popular and more democratic artistic expressions. On the other hand, the popular resists the elite artistic expressions and the logic of possessing art. The Banksy mural series, for example, of Girl with Balloon, that depicts a little girl whose balloon in the shape of a heart is taken by the wind, breaks with the uniqueness of a work of art since the artist painted a series of murals from London to the West Bank in Asia. Banksy reproduced re-readings of the "original" Girl with Balloon: he "reworked the painting to depict a Syrian refugee and added the hashtag \#WithSyria" and "in the 2017 United Kingdom general election, Banksy introduced a variant of Girl with Balloon with the balloon colored with the Union Jack design" ${ }^{\prime 1}$.

The re-readings in the form of supplements that Banksy creates point to the need for cultural translation while communicating meanings. In digital times, there are many more people acting as agents and producers of visual meanings, since the production of visual signs does not rest anymore in the hands of painters, cartoonists, film makers, comic strip artists or advertising agents but belongs to all of us, or in other words it is democratically distributed, and exposes the creativity of any person that moves in the

\footnotetext{
${ }^{11}$ Retrieved from: https://en.wikipedia.org/wiki/Girl_with_Balloon. Access on April 23, 2019.
} 
digital or contemporary society: youtubers, graffiti artists, meme creators, street artists, tattoo artists etc. Nevertheless, the postmodern and visual turns do not signal the end of the modern era but, actually, point to the coexistence of these two different perspectives in a variety of spheres of our everyday reality, one of them being the educational context. Moreover, in the artistic field, the postmodern turn is opening up to alternative ways of viewing reality:

In the spheres of art and architecture, we can point to the surfacing of postmodern in styles, the collapse of the hierarchical distinction between high art and popular art, an eclectic mixing of aesthetic codes, a nostalgia for past and local traditions, and a playful and ironic attitude instead of the moral seriousness of the modern aesthetic. These aesthetic shifts have been interpreted by some social analysts as part of a more general social and cultural "postmodern turn" in western societies (SEIDMAN, 1994, p. 02).

The multiplication of artwork in contemporary times includes its modification and variation that are consonant, many times, with the social campaigns the artist identifies with. On October $5^{\text {th }} 2018$, a framed copy of Banksy's artwork was put up for sale.

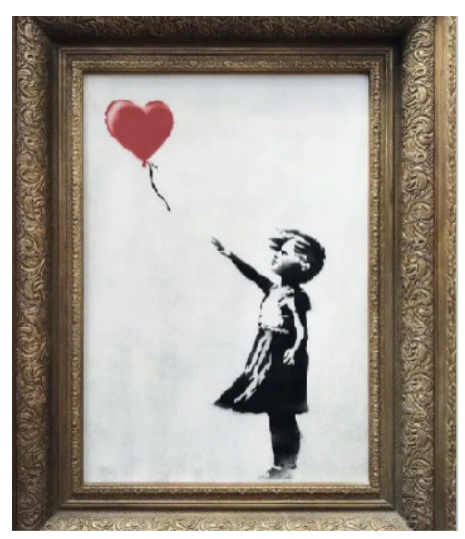

Image $8^{12}$

According to the Mercury website, moments after the closing bid, the artwork began to self-destruct by means of a hidden mechanical paper shredder that Banksy had built into the frame bottom. After the lower half of the painting shredded, Banksy released an image of the shredding on Instagram with the words "Going, going gone...".

\footnotetext{
${ }^{12}$ BANKSY. Girl with Balloon. Source: Page of The Mercury. Retrieved from: https://www.themercury.com.au/news/world/banksys-shredded-girl-with-balloon-renamed-love-is-in-thebin-says-sothebys/news-story/f5a2143c58c694661901dd35dbb459b3. Access on April 23, 2019.
} 


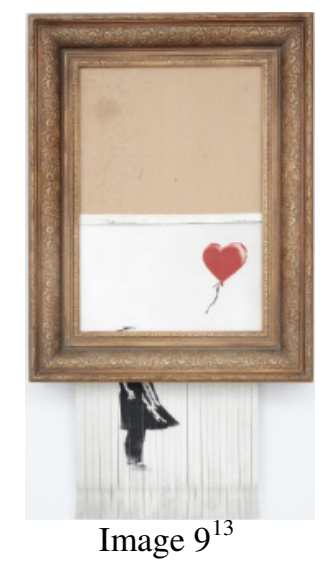

Later on, the controversial artist released a video of the shredding and how the shredder was installed into the frame in case the picture ever went up for auction. Sotheby's said "We have not experienced this situation in the past where a painting spontaneously shredded", leading some market watchers to speculate the remains of the painting will be worth even more.

Still according to Mercury, "The woman who won the bidding at the auction decided to go through with the purchase". The partially shredded work has been given a new title, Love Is in the Bin. Sotheby released a statement that called it "the first artwork in history to have been created live during an auction." ${ }^{14}$

In the process of constructing meaning out of the live rupture that Girl with Balloon suffers, we perceive visually the show of creation of an event out of a structure. Girl with Balloon in these terms would be seen as the "center... a point of presence, a fixed origin" (DERRIDA, 1978, p. 278). In the same vein, the reworking of the painting for the different contexts Banksy painted "must be thought of as a series of substitutions of center for center, as a linked chain of determinations of the center. Successively, and in a regulated fashion, the center receives different forms or names" (DERRIDA, 1978, p. 279). However, Love is in the Bin performs a shredding that exhibits visually how the event is from the very beginning part of the structure. The production of the event illustrates that the locus of enunciation of the producer or interpreter together with their meaning making affordances affect the understanding of any structure, or in other words, our understandings are situated.

\footnotetext{
${ }^{13}$ BANKSY. Banksy's Love is in the Bin. Source: Page of Aim at Art. Retrieved from: https://www.aimatart.nl/en/a-different-look-at-communication-get-inspired-by-banksy/. Access on April 23, 2019.

${ }^{14}$ Retrieved from: https://en.wikipedia.org/wiki/Girl_with_Balloon. Access on April 23, 2019.
} 
The supplement as an event is the alterity that as an absence seeks to gain visibility. The alterity, hidden by the dominance of discourses that seek to create a fictional center, an origin where all knowledge emanates from, creates "the movement of supplementary representation" that "approaches the origin as it distances itself from it" (DERRIDA, 1997, p. 295). This movement is the one of play:

If totalization no longer has any meaning, it is not because the infiniteness of a field cannot be covered by a finite glance or a finite discourse, but because the nature of the field - that is language and a finite language - excludes totalization. This field is in effect that of play, that is to say, because instead of being an inexhaustible field, as in the classical hypothesis, instead of being too large, there is something missing from it: a center which arrests and grounds the play of substitutions (DERRIDA, 1978, p. 289).

The example above of the Banksy mural series might help us understand the concept of supplements and supplementation by Derrida and thus our perspective on the Visual turn. In the Banksy case, clearly the supplement comes through the interplay between the relay of the physical mural and the live experience of its destruction. Through the movement of resignification, the unknown, the never-seen-before becomes visible, a presence that constructs the possibility of creating more visual language. This would be the play between absence and presence, the known and the unknown, one supplementing the other, leaving traces of their complementation since one needs the other in order to exist.

Our next example explains the concept of supplement as testimony to the absence of the metaphysical signifier. An example of how visual culture has been reshaped and relocated away from the "big" knowledge/arts production centers (e.g. Europe) is the re-reading of the work of art Las Meninas by Diego Velázquez. Waltercio Caldas, the Brazilian visual artist, produces a supplement of Velázquez's masterpiece that was exhibited at the Bienal of São Paulo in 2018. This supplement, the result of computer graphics, that is also part of a book that goes by the title Livro de Velázquez (1996), reinvents the space by cutting off the figures from the "original" painting. In this book, not only the images, but also the texts are out of focus, blurry, lacking precision or sharpness.

Vision, perspective, light, visibility/ invisibility, presence and absence are some of the themes that Foucault (1970) explores in his interpretation of Velázquez's Las meninas. However, "what it is 'about' - its meaning - depends on how we 'read' it. It is 
as much constructed around what you can't see as what you can" (HALL, 1997, p. 59). The representation of the Infanta Margarida and her courtesans is what occupies the main stage of the painting. All the represented participants in the picture are looking at the subject of the painting being drawn by the artist standing next to the Infanta's court. There is also a spectator of the whole scene standing at the illuminated doorstep in the depths of the painting. Theoretically, all of Velazquez's subjects are looking at the king and the queen, reflected in the mirror, or the most lighted "painting" hanging next to the doorstep at the back of the scene. At the same time, all participants are staring at the spectator, us, the ones who create and construct meanings from languages, may they be visual, verbal, gestural, facial, musical, performative...an infinite number of languages if we consider all cultural, animal, vegetative, climatic and other contexts.
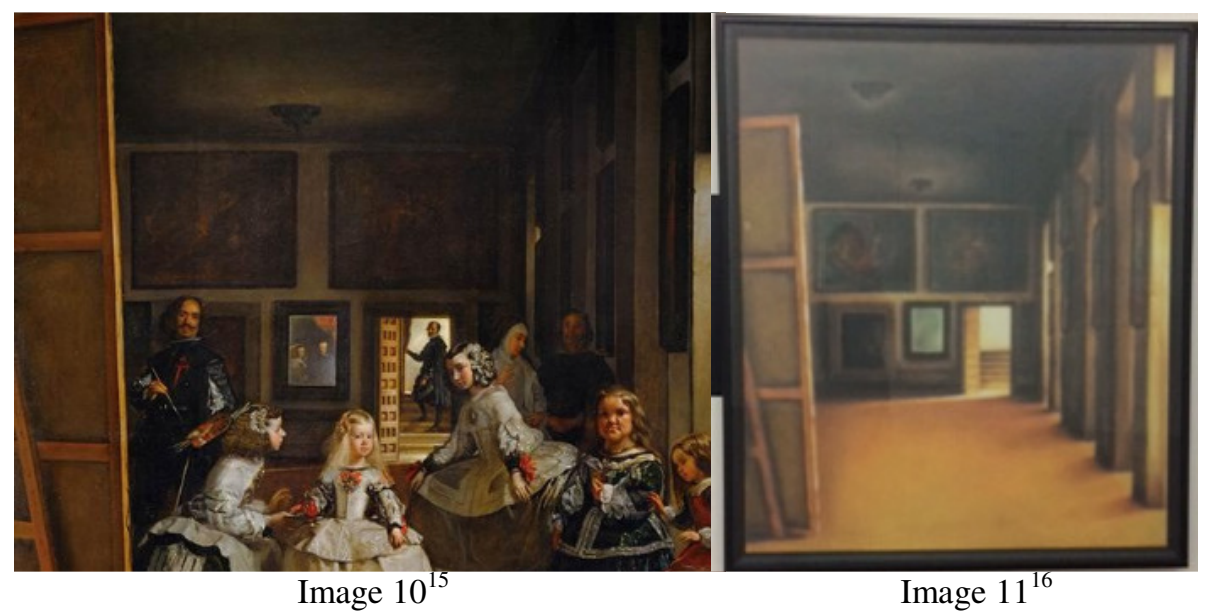

In Bakhtinian (1973) terms, we can say that the sign, the actual scene that Velázquez painted can only exist as representation. The whole scene is an invention whose elements could never appear synchronically in any "real" configuration since allegedly Velázquez is painting the king and the queen reflected in the mirror at the far back wall, while also making a self-representation of himself as the artist and depicting the Infanta and her maidens. What was Velasquez really looking at when painting this masterpiece? Therefore, the "real", the "truth", the actual existence of the sign is reinvented through representation, visual (the painting) or verbal (the word) or

\footnotetext{
${ }^{15}$ VELAZQUEZ. Las Meninas. Source: Site História das artes. Retrieved from: https://www.historiada sartes.com/sala-dos-professores/as-meninas-velazquez/. Access on April 23, 2019.

${ }^{16}$ VELAZQUEZ. Los Velazquez. Source: Bienal 2018 de São Paulo. Available at: https://www1.folha. uol.com.br/fsp/ilustrad/fq150202.htm. Access on April 23, 2019.
} 
visual/verbal (the memes mentioned earlier). The representation or signifier is constantly staring at the interpreter, us, to attribute or construct meaning, the signified, from the signifier. We feel that Velázquez's subjects are staring ironically at us, seekers of fixed meanings, children and heirs of the way of thinking modernity sought to establish, that shies away from definitions of language that relate it to questions of identity (MENEZES DE SOUZA, 2004, p. 114) and contingency (MENEZES DE SOUZA, 2009, p. 88).

Moreover, each of the diverse communities which constitute a socio-historic collectivity is subject to change through time; it is this that generates the potential complexity and multiplicity of readings produced in any given socio-historic collectivity. However it must be remembered that this multiplicity of readings are not equally valid even within the same sociohistoric collectivity: if the meanings and language of the texts written/read by a specific constitutive community are the product of the socio-historic characteristics of that community, then their validity also pertains only to that community and cannot be simply forcibly substituted by other meanings and language of other communities (MENEZES DE SOUZA, 2009, p. 88).

Los Velázquez, by Waltercio Caldas, not only deconstructs the famous painting by the Spanish artist, but also places a critique by eliminating the Spanish royal court characters and purposefully leaving the room empty, open for interpretation for the viewer. According to the Carioca artist, Velázquez had a strong relationship with the question of technical reproduction, if you consider the question of technical reproduction as if it were a mirror of another level. And he adds that various questions that the Livro de Velázquez raises are incorporated in the question of technical reproducibility, this element that intermediates between the Self and the real world. Waltercio Caldas defends that the role of art is to create more art. Therefore, the artist shouldn't let the previous object of art go to sleep since it is the new that maintains the old awake.

Derrida (1997) describes in detail this relation between the supplement and the source:

[t]he project of repeating the thing already corresponds to a social passion and therefore requires a metaphoricity, an elementary transference. One transports the thing within its double (that is to say already within an ideality) for another, and the perfect representation is always already other than what it doubles and re-presents... The duplication of the thing in the painting...opens appearance as the absence of the thing in its self-sameness and its truth (DERRIDA, 1997, p. 292). 
Los Velázquez effectively displaces the viewer's gaze away from a reading of the figures that participate in Velázquez painting and their perspective to the spatial aspect of the representation, recreating, in this manner another center that has always been present as part of the metaphysical signifier. For Derrida, presence exists when the signifier cannot contradict itself, when it is directly related to a meaning, the signified. This would create a reality where the meanings of the metaphysical signifier could be transparent and homogeneously interpreted. However, postmodernity (visually) constructs infinite supplements that deconstruct the metaphysical signifier as a center and turn absence into presence.

The displacements that are constantly occurring can also be conceived as translations of the metaphysical signifier that is culturally tinted. As Mignolo (2002) claims

[i]t is our assumption that translation is more than a syntactic and semantic
transaction between two languages. It involves also historical and
geopolitical configuration. Historical because a given language has a logic
but also a historical memory engrained and forming the subjectivity of the
speakers. For that reason, translation in the domain of language is at the same
time a phenomenon of transculturation (MIGNOLO; SCHIWY, 2002, p. 251-
252).

Hence, in terms of language and culture (Arts), it is possible to apprehend from Waltercio Caldas's art the urgent call for cultural translation: 1. Culture is not a synonym of Nation-state anymore, for the Spanish royalty can be replaced by any other people (the room is empty!); 2. Culture cannot be seen within binary oppositions, for high culture - in this painting - is erased since the philosophical questions about perspective and the gaze vanish from the scene; 3. Culture is not always the representative of the illuminism for local artists can answer back and redo/reinterpret iconic-European artists; 4. Culture does not always mean material artefacts for the very idea of museums is questioned in postmodernity with the exhibition of art in places previously seen as inadequate for contemplating art, such as airports; and finally, 5. We experience a global culture while local culture fights back for voice and visibility.

As we have seen so far, the Postmodern and the Visual turns need to be problematized epistemologically and ontologically for images and meaning making processes have never been innocent, neutral or taken-for-granted forms of language (lingua and linguagem), although modernity struggled to do establish fixed patterns of meaning. In contemporary ultra neoconservative times, it is of utmost importance that 
we language educators conceive of visuality as contextualized meaning making processes that deliberately build images and meanings of our communities, our sense of nationality, of ourselves and the Other. Without these understandings, dialogue within consensus and dissent, agonistically speaking, will be impossible.

\section{5. (IN)CONCLUSIONS}

There is still much to be discussed in relation to the prosuming of images we encounter every time we open our mobile phones, check our social media, or teach. However, it is time to close this conversation for now. This paper started with a focus on a crisis of representation in which images are no longer real mimesis of the visual object. Rather, as seen in Ugur Gallen's striking photographs, we are invited to plunge into the juxtaposition of images and ask ourselves: What is this contemporary world we live in? What are the consequences of such social and economic differences? How do $I$ look to/at/with the Other? This idea of representation as meaning making - put forward by Hall (1997), amongst others - is paramount if we are to look at visual culture, visuality and images otherwise.

The dialogic nature of images in contemporaneity constructs conceptual worlds through visual juxtaposition, and this has been augmented and potentialized by technologies, connectivity, social media, and mass media.

The postmodern turn and the visual turn have offered us not only the philosophical groundings to understand the presuming of images and our views about language (for example, Derrida's supplements, Bakhtin's dialogic and heteroglossic views of language), but have also provided us with the necessary tools to analyze images as contextualized, historicized, and glocalized meaning making processes. Thus, relocating and culturally translating the old saying, we conclude: Images do not speak for a thousand words. Instead, they create and recreate the world of signifying practices; they can also manipulate, and can represent a particular sided-view of a situation; they can be a decisive game player in a country's elections. For all of these aspects, images and visual culture need to be problematized in education, more specifically in language education and teacher education.

The last image we offer the reader is the sculpture below by Waltercio Caldas. The artist tries to reflect on language through visual art. His sculpture somehow changes 


\section{Dossiê Especial FICLLA}

REVISTA X, Curitiba, volume 14, n.5,p. 126-150, 2019

how we think about language and how we relate to things (signs). His artistic expression creates new possibilities to think about language by creating new visual interventions that restructure language giving it new possibilities of existence by attributing to it new meanings. Using stainless steel, glass and acrylic he creates a "structure" where the words NOT NOW are being reproduced through their reflections on the glass getting a mirror image of the written language.

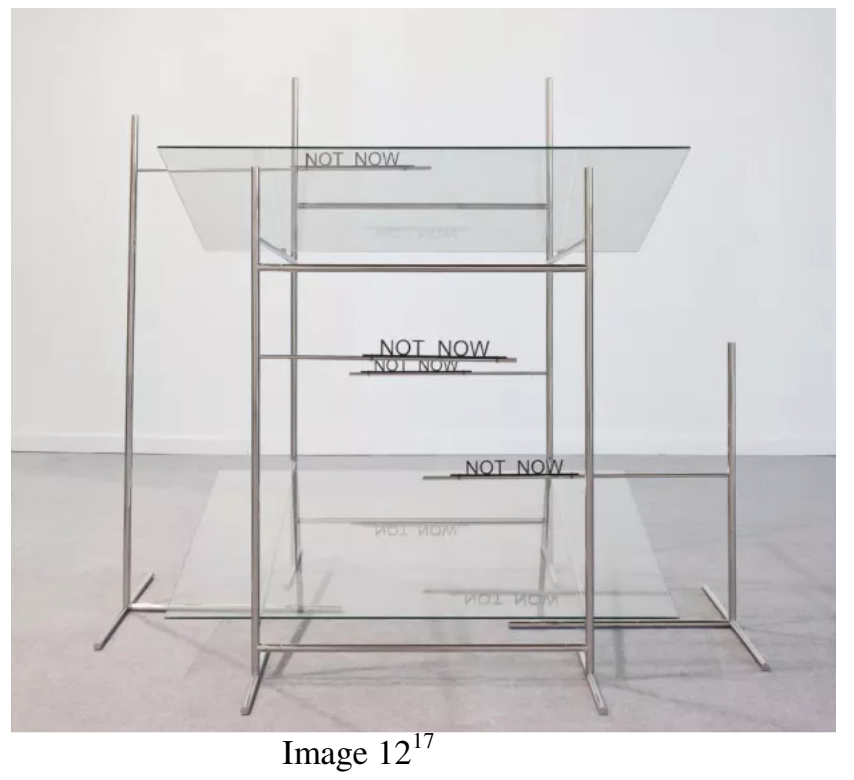

In the words of the author, the relation of language and vision has to do with creating a "new terrain that must deal with the previous terrain and, at the same time, create a new possibility for what is to come" ${ }^{" 18}$. What this artistic expression produces is

a field of vision version of Derrida's concept of différance and its achievement has had a twofold effect both on the structure of meaning and interpretation and on the epistemic and institutional frameworks that attempt to organize them. Derrida's conceptualization of différance takes the form of a critique of the binary logic in which every element of a meaning constitution is locked into signification in relation to the other...Instead what we have begun to uncover is the free play of the signifier, a freedom, to understand meaning in relation to images, sounds or spaces not necessarily perceived to operate in direct, causal or epistemic relation to either their context or to one another (ROGOFF, 2002, p. 25).

17 CALDAS. Not Now. Retrieved from: https://casavogue.globo.com/LazerCultura/Arte/noticia/ 2018/09/waltercio-caldas-seleciona-obras-que-falam-de-tempo-e-espaco-para-bienal-de-sp.html. Access on April 23, 2019.

18 Retrieved from: https://casavogue.globo.com/LazerCultura/Arte/noticia/2018/09/waltercio-caldasseleciona-obras-que-falam-de-tempo-e-espaco-para-bienal-de-sp.html. Access on April 23, 2019. 
As it is not enough to leave the reader with the "and now, what?" feeling, we end this paper with some problematizing-food-for-thought questions for those language educators who are now convinced that images do play a pivotal role in language education. The questionings comprise research projects and pedagogical practices we have developed in relation to visual literacies, visual culture and cultural studies over the years: How do I conceive of images as they appear daily from everywhere? How have I worked with images in the classroom as they appear in textbooks, websites, books chapter and articles? In the case of movies, do I maintain or condemn the old practice of "cutting classes by showing a movie" to my students? And if I condemn the practice, but insist on a critical discussion of relevant themes though movies, which ones have I chosen to discuss with my students? Are they relevant for that group or am I imposing those movies because I like them? Which epistemological discussions need to be carried out with my students in order to problematize language, representation, visual representation, visual culture and meaning making? How do I negotiate visual meaning making and interpretations in my classes? Our hope is to have demonstrated here that images - seen through Postmodern and Visual turns - can help us envision and promote critical and active citizenship in language education.

\section{REFERENCES}

ALCOFF, L. M. New Epistemologies: Post-Positivist Accounts of Identity. In: WETHERELL, M.; MOHANTY, C. T. (Ed.), The Sage Handbook of Identities. Los Angeles and London: Sage Publications, 2010.

BAKHTIN, M. (Volosinov). The dialogic Imagination. Austin: University of Texas, 1981.

BAKHTIN, M. (Volosinov). Marxism and the Philosophy of Language. New York: Seminar Press, 1973.

DERRIDA, J. Structure, Sign and Play in the Discourse of the Human Sciences. In: DERRIDA, J. Writing and Difference, translated by Alan Bass. Chicago: University of Chicago Press, p. 278-93, 1978.

DERRIDA, J. Of Grammatology. Translated by Spivak, G. C. The John Hopkins University Press, Baltimore and London, 1997.

FOUCAULT, M. Genealogy and Social Criticism. In: SEIDMAN, S. (Ed.). The Postmodern turn: new perspectives on social theory. Cambridge: Cambridge University Press, 1994. 
FOUCAULT, M. The Order of Things: an archeology of the human sciences. London: Tavistock Publications Ltd., 1970.

GALLEN, U. Instagram (personal profile). Retrieved from: https://www.instagram.com/ p/Brsidbnh2Zm/?utm_source=ig_share_sheet\&igshid=04laqv6vox8f. Access on Feb. 20, 2019.

HALL, S. Representation: Cultural representation and Signifying Practices. London, Thousand Oaks, New Delhi: Sage Publications, 1997.

KALANTZIS, M.; COPE, B. Language Education and Multiliteracies. In: MAY, S.; HORNBERGER N. H. (Eds). Encyclopedia of Language and Education, v. 1, Springer, p.195-211, 2008.

KINCHELOE, J. L.; McLAREN, P.; STEINBERG, S. R.; MONZÓ, L. Critical pedagogy and qualitative research: Advancing the bricolage. In: DENZIN; LINCOLN (Eds.) The SAGE Handbook of Qualitative Research, 5th ed., Thousand Oaks, CA: Sage, p. 235-260, 2017.

LYOTARD, J. F. The postmodern condition: A report on knowledge. Minnesota: University of Minnesota Press, 1984.

MENEZES DE SOUZA, L. M. T. Hibridismo e Tradução Cultural em Bhabha. In: ABDALA JUNIOR, B. (Org.). Margens da Cultura: mestiçagem, hibridismo \& outras misturas. São Paulo: Boitempo, 2004.

MENEZES DE SOUZA, L. M. T. Hibridismos e tradução cultural: reflexões. Trab. Linguist. Apl., Campinas, v. 46, n. 1, p. 9-17, 2007.

MENEZES DE SOUZA, L. M. T. Gaza 2009: notes on critically reading conflict. Critical Literacy: Theories and Practices, vol. 3, issue 1, 2009.

MIGNOLO, W. D.; SCHIWY, F. Beyond Dichotomies: Translation/Transculturation and the Colonial Difference. In: MUDIMBE-BOYI, E. (Ed.). Beyond Dichotomies: Histories, Identities, Cultures, and the Challenge of Globalization. Albany: State University of New York Press, p. 251-286, 2002.

MIRZOEFF, N. The Visual Culture Reader. London: Routledge, 1998.

PETERS, M. A.; BIESTA, G. Derrida, Deconstruction, and the Politics of Pedagogy. New York: Peter Lang, 2009.

PRATT, M. L. Imperial Eyes: Travel Writing and Transculturation. New York: Routledge, 1992.

ROJO, R.; MOURA, E. Multiletramentos na escola. São Paulo: Parábola, 2012.

ROSA, J. G. A terceira margem do rio. In: ROSA, G. Primeiras estórias. Rio de Janeiro: Editora Nova Fronteira, 1962. 
ROGOFF, I. Studying Visual Culture. In: MIRZOEFF, N (Ed.). The Visual Culture Reader. 2 ed. London \& New York: Routledge, p. 24-36, 2002.

SEIDMAN, S. The Postmodern Turn: new perspectives on social theory. Cambridge: Cambridge University Press, 1994.

SHOHAT, E.; STAM, R. Narrativizing visual culture. Towards a polycentric aesthetic. In: MIRZOEFF, N. (Ed.) The Visual Culture Reader. 2ed. London \& New York: Routledge, p. 27-49, 2002.

SOUSA SANTOS, B. The End of the Cognitive Empire: the coming of age of epistemologies of the South. Durham and London: Duke University Press, 2018.

TAGG, C. Heteroglossia in text-messaging: performing identity and negotiating relationships in a digital space. Journal of Sociolinguistics, 20(1), p. 59-85, 2016.

TAGGART, E. Slip photos show Eye-Opening Differences between Western World and War-Torn Middle East. My Modern Met: Share, inspire, connect (online), 2018. Disponível em: https://mymodernmet.com/digital-collage-syrian-war-contrast-ugurgallenkus/ Acesso em 20 nov. 2019.

TAPSCOTT, D.; WILlIAMS, A. D. The Prosumers. In: Wikinomics: how mass collaboration changes everything. New York, USA: Penguin Books, p. 124-150, 2007.

TODD, S. Toward an Imperfect Education: Facing humanity, Rethinking Cosmopolitanism. New York: Routledge, 2016.

WEI, L.; GARCÍA, O. (Eds.) Translanguaging: Language, Bilingualism and Education. New York: Palgrave Macmillan, 2014. 